\title{
Quality of 'Delta Valencia' orange grown in semiarid climate and stored under refrigeration after coating with wax
}

Gerlândia da Silva PEREIRA ${ }^{1 *}$, Francisca Ligia de Castro MACHADO ${ }^{1}$, José Maria Correia da COSTA ${ }^{1}$

\begin{abstract}
The effects of carnauba-based wax on the quality of 'Delta Valencia' orange produced in Ceará state, Brazil, were studied. The fruits were coated with carnauba-based wax and refrigerated $\left(7 \pm 2{ }^{\circ} \mathrm{C}\right.$ and $85 \pm 2 \%$ R.H.) for 28 days. The quality attribute parameters assessed were weight loss, peel color (brightness, hue angle, and chromaticity), peel moisture, $\mathrm{pH}$, soluble solids (SS), titratable acidity (TA), SS/TA ratio, ascorbic acid, total soluble sugars, reducing sugars, yellow flavonoids, and polyphenols. The results showed that 'Delta Valencia' oranges grown in the dry climate of Ceará state has excellent quality. The coated fruits lost mass at a lower rate than the the control fruits. No significant loss of soluble solids, titratable acidity, pH, and SS/TA ratio was observed, while ascorbic acid, soluble sugars, reducing sugars, yellow flavonoids, and polyphenols increased during storage in both the coated and control fruits. Carnauba-based wax coated fruits showed no signal of dehydration keeping their shiny green peel up to the end of the storage. The use of coating was crucial for the maintenance of visual quality by reducing mass loss, as well as keeping peel moisture.
\end{abstract}

Keywords: Citrus sinensis; postharvest quality; coating.

\section{Introduction}

The citrus is one of the fastest growing and most competitive agricultural sectors. Brazil is the world's largest citrus producer, and it contributes with approximately $28 \%$ of the world production, especially orange (TAZIMA et al., 2008). The Northeast region is the second largest producer in the country, and Bahia and Sergipe states are the leading regional producers (AZEVÊDO, 2010). The semiarid Northeast is divided into several areas, in which the agribusiness centers are located. Among those, Jaguaribe, a municipality in the state of Ceará, stands out for its deep, rich soil and water availability, essential features for the development of a successful irrigation system, suitable for a more technical agriculture., Jaguaribe, known nationwide for the production of crops such as banana and melon, has been welcoming new crops such as grapefruit and sweet oranges, among those are 'Salustiana', 'Navelina', and 'Delta Valencia'.

The sweet 'Delta Valencia' orange stands out for its quality and juiciness (AULER; FIORI-TUTIDA; SCHOLZ, 2009). External quality indices are color intensity and uniformity, firmness, size, shape, and smoothness. Flavor quality is related to the soluble solids/acid ratio and absence of off-flavor-causing compounds, including fermentative metabolites (ARPAIA; KADER, 2011). However, since carbohydrate and organic acids contents are greatly dependent on climatic conditions (VOLPE; SCHÖFFEF; BARBOSA, 2002), among other factors, soluble solids/acid ratios are not inflexible and may vary according to the fruit growing areas.

Thus, studies focusing on the quality of fruit grown under local conditions are mandatory. In addition to carbohydrates and organic acids, oranges are source of ascorbic acid, flavonoids, and phenolics, which are compounds that have proved to benefit human health through their free radical scavenging property (WU; GUAN; YE, 2007). These compounds, however, may oxidize during storage decreasing fruit internal quality.

The most reliable technology used to reduce fruit compositional changes during storage is the optimization of temperature and relative humidity. Nonetheless, while fruit internal quality is important for human health, consumers base their purchasing decisions on perceptual characteristics, such as peel dehydration, fruit softening, and fading of color. To maintain fruit internal and external quality at the most during storage, it is necessary the association of optimal storage conditions with complementary treatments. Wax has been used to preserve fruit quality during storage, but at the same time it reduces peel dehydration, maintains color intensity, and adds shine to the peel (MACHADO; COSTA; BATISTA, 2012), some commonly used citrus coatings, especially the less permeable ones, may cause ethanol accumulation due to anaerobic conditions (HAGENMAIER, 2002).

This study aims at evaluating quality attributes of 'Delta Valencia' oranges produced in the warm and dry climatic condition, typical of Ceará state, and the effect of low temperature associated to waxing on the maintenance of fruit internal and external quality.

\section{Materials and methods}

'Delta Valencia' orange [Citrus sinensis (L.) Osbeck] grafted on 'Swingle' citrumelo [Citrus paradisi Macfad. x Poncirus trifoliata (L.) Raf.] were grown in the city of Jaguaribe county $\left(5^{\circ}\right.$

\footnotetext{
Received 23/5/2012

Accepted 14/2/2013 (005715)

1 Centro de Ciências Agrárias, Universidade Federal do Ceará - UFC, Av. Mister Hull, 2977, CP 12168, CEP 60021-970, Fortaleza, CE, Brasil,

e-mail: gerlandiasp@ibest.com.br

${ }^{*}$ Corresponding author
}

DOI: http://dx.doi.org/10.1590/S0101-20612013005000036 
$20^{\prime}$ South latitude and $38^{\circ} 5^{\prime}$ West longitude) and were harvested in November 2010, area with annual average temperature of $28.5{ }^{\circ} \mathrm{C}$, irregular rainfall pattern of $772 \mathrm{~mm}$ average, relative humidity of $62 \%$, and solar radiation of 3,030 hours (DEPARTAMENTO..., 2011).

The fruits were harvested in the morning, packed in cardboard boxes, and transported under refrigerated to the Federal University of Ceará, Department of Food Science. They were sorted out for shape, size, and color intensity. Next, the fruits were rinsed with tap water, dried under forced ventilation, immersed or not in wax, Aruá Tropical - diluted in distilled water (1v:1v), and stored under refrigeration $\left(7 \pm 2{ }^{\circ} \mathrm{C}\right.$ and $85 \pm 2 \%$ R.H.) for 28 days.

The analyses were performed upon harvest and every four days up to end of the storage period. Non-destructive analyses were fruit mass $(\mathrm{g})$, length $(\mathrm{mm})$, width $(\mathrm{mm})$, loss of weight and external color, while destructive analysis were puncture force, juice content, peel moisture content, $\mathrm{pH}$, soluble solids, titratable acidity, soluble solids/titratable acidity ratio, ascorbic acid, soluble sugars, reducing sugars, yellow flavonoids, and polyphenols.

Mass loss was determined by weighing each numbered fruit individually during storage and calculating mass loss in relation to fruit mass at harvest. The results were expressed as percentage. Fruit peel color was measured at opposite sides (previously marked) on the equatorial region of the fruit. The color was determined using a Minolta CR-300 colorimeter, and the data were expressed as hue, brightness, and chromaticity. Peel moisture content was calculated on dry weight basis. Approximately $5 \mathrm{~g}$ of peel sample was weighed in an aluminum container and dried in hot air oven at $80{ }^{\circ} \mathrm{C}$ for 24 hours. Juice content was calculated by weighing fruit juice and dividing it by fruit mass. The results were expressed as percentage. Puncture resistance was assessed using a force gauge (model DD-200) fitted with a $5 \mathrm{~mm}$ cylindrical probe in the probe carrier. The oranges were placed on a flat plate with the stem calyx axis parallel to the surface of the plate. Puncture resistance, expressed as $\mathrm{N}$, was recorded as the maximum force required to puncturing the fruit surface. Soluble solids were determined with a digital refractometer (Model PR-100 Palette, Atago Co.) according to AOAC, (ASSOCIATION..., 1995) and the results expressed in ${ }^{\circ} \mathrm{Brix}$; $\mathrm{pH}$ was determined with a digital potentiometer (ASSOCIATION..., 1995); acidity was determined by titration with $0.1 \mathrm{M} \mathrm{NaOH}$ and expressed as (\%) of citric acid (INSTITUTO..., 2004); and the soluble solids/titratable acidity ratio was determined. Determination of ascorbic acid content was performed according to Strohecker and Henning (1967), and the results were expressed in $\mathrm{mg}$ of ascorbic acid/100 g of juice. Soluble sugars contents were determined according to Yemn and Willis (1954), and the results were expressed in percentage. The content of reducing sugars was determined using the method described by Miller (1959), and the results were expressed in percentage. Yellow flavonoids evaluation followed the methodology described by Francis (1982); and the results were expressed in $\mathrm{mg} / 100 \mathrm{~g}$. Total polyphenols was assessed using the Folin-Ciocalteau reagent. Gallic acid was used as the standard, according to the method described by Bucic-Kojic et al. (2007); and the results were expressed in $\mathrm{mg}$ GAE/100 $\mathrm{mL}$.

The experimental design was a randomized complete block in a split-plot arrangement. The plots in the ANOVA were treatments (main plot) and time of storage (sub-plot) with ten replications for non-destructive analyses and four replications for destructive analyses. Linear regressions were used to describe trends during storage $\left(\mathrm{R}^{2} \geq 70 \%\right)$, according to the procedure available in SISVAR version 4.1. Mean separation was performed using the Tukey's test $(\mathrm{p} \leq 0.05)$.

\section{Results and discussion}

'Delta Valencia' orange grafted on 'Swingle' citrumelo and grown in warm climate in the state of Ceará had solid, green peel color with average hue angle, chromaticity, and brightness at harvest of $120.00 ; 27.00$, and 46.00 , respectively. The fruits were firm, with average puncture force of $60 \mathrm{~N}$, and round with average length and width of 85.20 and 84.80 , respectively. Average fresh mass was $319 \mathrm{~g}$, while average juice content was $43 \%$. These values are slightly different from those reported by Tazima et al. (2008) for 'Valencia Late 1138' orange grafted on 'Rangpur' lime and grown in subtropical conditions (latitude $23^{\circ}$ $22^{\prime} \mathrm{S}$ and longitude $51^{\circ} 10^{\prime} \mathrm{W}$ ). In that study, the average fruit mass and juice content were $183.16 \mathrm{~g}$ and $48.9 \%$, respectively. The difference in mass loss and juice content in oranges grown in different areas in the country may result from different climatic conditions, as well as the scion-rootstock interactions since these factors greatly affects fruit quality (AULER; FIORI-TUTIDA; SCHOLZ, 2009). It is worth mentioning that the force required to puncture the peel and the juice content in wax-coated fruits did not differ from those of the control fruits $(\mathrm{p}<0.05)$. Furthermore, the average values at harvest did not differ from those at the end of the storage $(\mathrm{p}<0.05)$ (data not shown), probably due to the appropriated storage condition $\left(7^{\circ} \mathrm{C}\right.$ and $85 \%$ R.H.) capable of reducing fruit metabolism.

The effect of wax-based coating applied to the 'Delta Valencia' oranges in association with low temperature storage on the reduction of fruit loss of mass was significant. Waxcoated fruits lost mass at a lower rate than the control fruits during storage (Figure 1a). At the end of the storage, control fruits lost $3.16 \%$ of their initial mass, while wax-coated fruits lost only $1.44 \%$. Fruit decrease in mass during storage is directly associated with loss of moisture, which results in quantitative and qualitative losses. According to Ladaniya (2008), loss of moisture higher than $6 \%$ might compromise fruit quality, rendering it unacceptable for marketing. In the present study, moisture loss results were smaller than the limits considered unacceptable for marketing for both wax-coated and control fruits. However, loss of moisture in the wax-coated fruit was kept to a minimal up to the end of the storage period, and therefore the wax-coated fruit had higher external quality. This study corroborates the finding reported by Malgarim, Cantillano and Treptow (2007), who found that waxed 'Navelina' orange lost mass at a lower rate than that of the control fruit during storage.

Peel brightness was not affected by waxing $(\mathrm{p}<0.05)$ and varied very little during storage, following a third degree polynomial 
equation $\left(\mathrm{Y}=47.1732-0.2112 \mathrm{x}+0.0169 \mathrm{x}^{2}-0.0002 \mathrm{x}^{3}\right.$, $\left.\mathrm{R}^{2}=98.36 \%\right)$. This finding does not agree with those reported by Malgarim, Cantillano and Treptow (2007). According to those authors cold stored 'Navelina' oranges showed a decrease in brightness during storage, while wax-coated fruits showed an increase in brightness. Different brightness trends during storage might be related to fruit maturity at harvest, as well as the chlorophyll content characteristic of each cultivar. Hue angle was strongly influenced by the interaction between coating and storage periods $(\mathrm{p}<0.05)$. Although both uncoated and coated fruits became less green during storage, decrease in hue angle in coated fruits was lesser than that of the control fruits (Figure 1b). That implies that the application of wax retarded peel maturation, and consequently color changes. Considering that local consumers associate green peel color with fruit quality, it may be stated that the application of wax contributes to the extension of the storage life of 'Delta Valencia' oranges grown in semiarid climate by maintaining their green peel over longer period of time. Chromaticity of wax-coated fruits did not differ from that of control fruits $(\mathrm{p}<0.05)$ but changed according to storage durations $\left(\mathrm{Y}=26.1163+0.0851 \mathrm{x}, \mathrm{R}^{2}=98.95 \%\right)$. Chromaticity trends during storage were the opposite of those observed for brightness and similar to those observed for hue angle. These results suggest that peel color became brighter, less green, and more vivid during storage. Nonetheless, wax-coated fruits stood out for preserving an uniform green color.

The peel moisture content of 'the wax-coated fruits differed from that of the control fruits $(\mathrm{p}<0.05)$, but it remained stable during storage in both treatments (Table 1). Although differences between the moisture levels in the control and waxed-coated fruits were not always significant $(\mathrm{p}<0.05)$, the moisture content of waxed-coated fruits was always higher than that of the control fruits. Water loss reduction in wax coated fruits results from skin pore blockage, which reduces skin permeance to water vapor and gases. This reduction in moisture might have directly accounted for the weight maintenance in wax-coated fruits observed in Figure 1a. On the other hand,
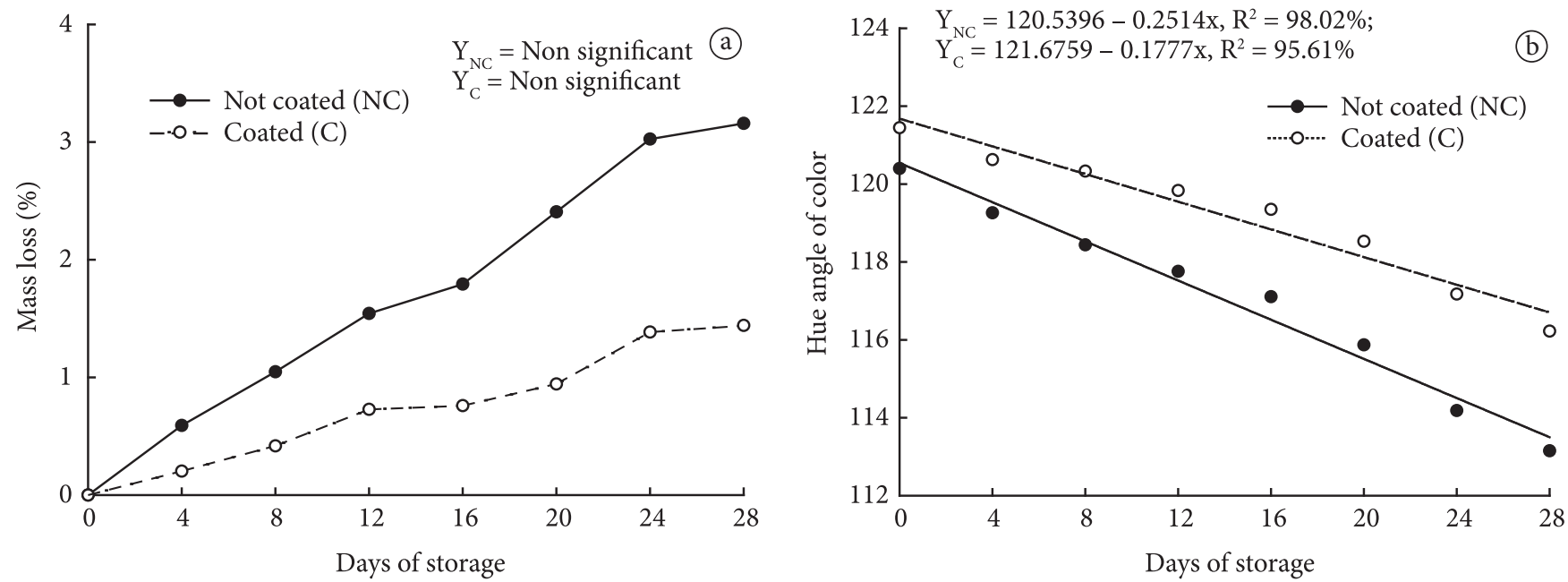

Figure 1. Trends in mass loss (a) and trends in hue angle (b) during storage in 'Delta Valência' oranges wax coated and cold stored.

Table 1. Peel moisture content, soluble solids ('Brix), titratable acidity (TA) (mg citric acid/100g juice), and SS/AT ratio in 'Delta Valência' oranges coated with wax and cold stored ${ }^{1}$.

\begin{tabular}{|c|c|c|c|c|c|c|c|c|}
\hline \multirow{2}{*}{ Treatament } & \multicolumn{8}{|c|}{ Days in storage } \\
\hline & 0 & 4 & 8 & 12 & 16 & 20 & 24 & 28 \\
\hline & \multicolumn{8}{|c|}{ Peel moisture (\%) } \\
\hline Not coated & $69.36 \mathrm{aA}$ & $68.79 \mathrm{aA}$ & $68.92 \mathrm{aA}$ & $66.79 \mathrm{aA}$ & $68.12 \mathrm{aA}$ & $69.21 \mathrm{aA}$ & $71.07 \mathrm{aA}$ & $70.65 \mathrm{aA}$ \\
\hline \multirow[t]{2}{*}{ Coated } & $69.36 \mathrm{aA}$ & $69.89 \mathrm{aA}$ & $72.87 \mathrm{aB}$ & $71.59 \mathrm{aB}$ & $70.92 \mathrm{aA}$ & $73.69 \mathrm{aB}$ & $72.63 \mathrm{aA}$ & $72.15 \mathrm{aA}$ \\
\hline & \multicolumn{8}{|c|}{ Soluble solids ( ${ }^{\circ}$ Brix $)$} \\
\hline Not coated & $9.63 \mathrm{a}$ & $9.28 \mathrm{a}$ & $10.08 \mathrm{a}$ & $9.68 \mathrm{a}$ & $10.88 \mathrm{a}$ & $10.48 \mathrm{a}$ & $9.78 \mathrm{a}$ & $9.50 \mathrm{a}$ \\
\hline \multirow[t]{2}{*}{ Coated } & $9.63 \mathrm{a}$ & $8.98 \mathrm{a}$ & $10.65 \mathrm{a}$ & $10.32 \mathrm{a}$ & $10.68 \mathrm{a}$ & $9.78 \mathrm{a}$ & $9.50 \mathrm{a}$ & $9.38 \mathrm{a}$ \\
\hline & \multicolumn{8}{|c|}{ Titratable acidity (\% citric acid) } \\
\hline Not coated & $0.38 \mathrm{a}$ & $0.40 \mathrm{a}$ & $0.48 \mathrm{a}$ & $0.53 \mathrm{a}$ & $0.48 \mathrm{a}$ & $0.46 \mathrm{a}$ & $0.43 \mathrm{a}$ & $0.43 \mathrm{a}$ \\
\hline \multirow[t]{2}{*}{ Coated } & $0.38 \mathrm{a}$ & $0.39 \mathrm{a}$ & $0.49 \mathrm{a}$ & $0.44 \mathrm{a}$ & $0.43 \mathrm{a}$ & $0.52 \mathrm{a}$ & $0.41 \mathrm{a}$ & $0.52 \mathrm{a}$ \\
\hline & \multicolumn{8}{|c|}{ SS/AT ratio } \\
\hline Not coated & $25.34 \mathrm{a}$ & $23.20 \mathrm{a}$ & $20.97 \mathrm{a}$ & $18.26 \mathrm{a}$ & $22.64 a$ & $22.76 \mathrm{a}$ & $22.75 a$ & $22.09 \mathrm{a}$ \\
\hline Coated & $25.34 \mathrm{a}$ & $23.02 \mathrm{a}$ & $21.73 \mathrm{a}$ & $23.48 \mathrm{a}$ & $24.84 \mathrm{a}$ & $18.81 \mathrm{a}$ & $23.17 \mathrm{a}$ & $18.04 \mathrm{a}$ \\
\hline
\end{tabular}

${ }^{1}$ Means followed by the same lower case letters in a row and same capital letter in a column did not differ significantly according to the Tukey's test $\mathrm{p} \leq 0.05$. 
moisture content stability during storage might be due to the storage conditions, such as low temperature and high relative humidity, $7^{\circ} \mathrm{C}$ and $85 \%$, respectively.

Soluble solids content was not influenced by waxing $(\mathrm{p}<0.05)$, but it slightly changed during storage $\left(\mathrm{Y}=9.2838+0.1407 \mathrm{x}-0.0049 \mathrm{x}^{2}, \mathrm{R}^{2}=70 \%\right)$. The soluble solids are related to fruit quality and are used as an indicative of fruit maturity, and therefore contribute greatly to fruit flavor. The soluble solids average obtained in this study, 9.9 Brix, is comparable to that reported by Tazima et al. (2008) for 'Valencia', and 'Valencia 718' oranges grown in subtropical climate and surpasses the minimum value, 9.0 Brix, required for sweet orange in Florida, U.S.A. (UNITED..., 1997). Considering that climate conditions greatly affect soluble solids levels, it may be stated that 'Delta Valencia' oranges grown in semiarid climate, found in Ceará state, has appropriated sweetness.

Titratable acidity was not affected by waxing $(\mathrm{p}<0.05)$, and although the averages did not significantly differ $(\mathrm{p}<0.05)$ from harvest to the end of the storage (Table 1), there was an increase in acidity in the fruits in both treatments. This finding is in agreement with that reported by Rapisarda et al. (2008), who, studying compositional trends during storage in five different orange genotypes, observed an increase in the citric acid content of 'Valencia' oranges and a decrease in the remaining varieties. Regarding fruit internal quality, acidity of 'Valencia' oranges grafted on 'Swingle' citrumelo and grown in dry, warm climate, as that of Ceará state, is less acidic than 'Valencia' oranges grafted on 'Rangpur' lime and grown in subtropical climate (TAZIMA et al., 2008). Waxing did not affect fruits' $\mathrm{pH}(\mathrm{p}<$ 0.05 ), and the readings taken during storage were statistically equal; the highest and lowest values ranged from 4.51 to 4.39 for the uncoated fruits, and from 4.51 to 4.22 for the coated fruits.

The SS/TA ratio was not affected by waxing, and the small variations that occurred during storage were not due to differences in storage time $\left(\mathrm{Y}=31.8307+0.8607 \mathrm{x}-0.0229 \mathrm{x}^{2}\right.$, $\mathrm{R}^{2}<70 \%$ ). The lowest SS/AT ratio average, 18.25 , was observed at the end of the storage period (Table 1) and was higher than the highest value reported by Auler, FIORI-Tutida and Scholz (2009) and Rapisarda et al. (2008) for 'Valencia' oranges grown in mild climate conditions. Auler, Fiori-Tutida and Scholz (2009), studying the effect of six rootstocks on quality of 'Valencia' oranges, observed that SS/TA ratio did not differ with the rootstocks. In that study, 'Troyer' citric rootstock yielded the highest SS/AT ratio, 12.0. Thus, it may be said that the warm and dry local climate conditions greatly contributed to the high levels of SS and low levels of acidity, and, consequently, high levels of SS/AT ratio in 'Delta Valencia' oranges.

Total and reducing sugars were influenced by the interaction of waxing and storage time $(\mathrm{p}<0.05)$ (Table 2). Sugar trends during storage in the control fruits followed a second degree polynomial equation $\left(\mathrm{Y}_{\text {Total sugar }}=6.3209+0.2393 \mathrm{x}-0.0033 \mathrm{x}^{2}\right.$ $\mathrm{R}^{2}<70 \%$ and $\mathrm{Y}_{\text {Reducing sugars }}=2.7884+0.1010 \mathrm{x}-0.0024 \mathrm{x}^{2}, \mathrm{R}^{2}<$ $70 \%)$, and the waxed fruits followed a third degree polynomial equation $\left(\mathrm{Y}_{\text {Total sugar }}=6.5361+0.5245 \mathrm{x}-0.0412 \mathrm{x}^{2}+0.0009 \mathrm{x}^{3}, \mathrm{R}^{2}\right.$ $<70 \%$ and $Y_{\text {Reducing sugars }}=2.8764+0.2681 \mathrm{x}-0.0256 \mathrm{x}^{2}+0.0006 \mathrm{x}^{3}$, $\mathrm{R}^{2}<70 \%$ ), suggesting that the control fruits had higher levels of sugars toward the end of the storage. Flavor is fundamentally the balance between sugar and acid and, in addition, specific flavor constituents are often glycosides. The sugar contents found in the present study are within the range reported in the literature for sweet oranges, maximum of 11.98 and minimum of $3.96 \%$ of fresh weight for total soluble sugar, and maximum of 5.8 and minimum of $2.6 \%$ of fresh weight for reducing sugar (HULME, 1970).

Vitamin C levels were not affected by waxing; the increase that occurred during storage is due to variations in storage time $\left(\mathrm{Y}=31.8307+0.8607 \mathrm{x}-0.0229 \mathrm{x}^{2}, \mathrm{R}^{2}=70 \%\right)$. In the present study, the ascorbic acid content, factor of great importance to human health and considered to be a sugar derivate, followed

Table 2. Total soluble sugars, reducing sugars, vitamin C (mg ascorbic acid/100g juice), total phenolic content, and yellow flavonoids in 'Delta Valência' oranges coated with wax and cold stored ${ }^{1}$.

\begin{tabular}{|c|c|c|c|c|c|c|c|c|}
\hline \multirow{2}{*}{ Treatament } & \multicolumn{8}{|c|}{ Days in storage } \\
\hline & 0 & 4 & 8 & 12 & 16 & 20 & 24 & 28 \\
\hline & \multicolumn{8}{|c|}{ Total soluble sugars (\%) } \\
\hline Not coated & $6.68 \mathrm{aA}$ & $6.87 \mathrm{aA}$ & 8.32abA & 6.96abA & $10.74 \mathrm{cA}$ & $10.76 \mathrm{cA}$ & $9.01 \mathrm{bcA}$ & $10.59 \mathrm{cA}$ \\
\hline Coated & \multicolumn{8}{|c|}{ Reducing sugars (\%) } \\
\hline Not coated & $2.98 \mathrm{aA}$ & $3.10 \mathrm{aA}$ & $2.89 \mathrm{aA}$ & $3.88 \mathrm{aA}$ & $4.20 \mathrm{aA}$ & $3.53 \mathrm{aA}$ & $4.05 \mathrm{aA}$ & $3.60 \mathrm{aA}$ \\
\hline Not coated & $32.50 \mathrm{ab}$ & $34.25 \mathrm{ab}$ & $29.75 a$ & $41.50 \mathrm{~b}$ & $38.55 \mathrm{ab}$ & $40.73 b$ & $35.75 \mathrm{ab}$ & $39.50 \mathrm{ab}$ \\
\hline \multirow[t]{2}{*}{ Coated } & $32.50 \mathrm{a}$ & $36.69 \mathrm{ab}$ & $35.98 \mathrm{ab}$ & $43.80 \mathrm{~b}$ & $38.42 \mathrm{ab}$ & $43.76 \mathrm{~b}$ & $38.32 \mathrm{ab}$ & $37.49 \mathrm{ab}$ \\
\hline & \multicolumn{8}{|c|}{ Total phenolic content (mg GAE/100 mL) } \\
\hline Not coated & $32.47 \mathrm{a}$ & $33.19 \mathrm{a}$ & $31.73 \mathrm{a}$ & $35.59 \mathrm{abc}$ & $34.59 \mathrm{ab}$ & $35.54 \mathrm{abc}$ & $38.67 \mathrm{bc}$ & $39.54 c$ \\
\hline Coated & $32.47 \mathrm{ab}$ & $30.52 \mathrm{a}$ & $34.48 \mathrm{abc}$ & $32.65 \mathrm{ab}$ & $34.06 \mathrm{abc}$ & $34.98 \mathrm{abc}$ & $36.89 \mathrm{bc}$ & $38.24 \mathrm{c}$ \\
\hline
\end{tabular}

${ }^{1}$ Means followed by the same lower case letters in a row and same capital letter in a column did not differ significantly according to the Tukey's test $\mathrm{p} \leq 0.05$. 
similar trends to those observed for total soluble sugars, as described above. Increasing levels of ascorbic acid in 'Delta Valencia' oranges during room and refrigerated storage were observed by Pereira et al. (2011). The average amount of vitamin $\mathrm{C}$ found in this study, $37.53 \mathrm{mg}$ ascorbic acid/100 g juice, is lower than that reported by Machado, Oliveira and Costa (2011) for 'Ruby Red' and 'Star Ruby' grapefruit also using 'Swingle' citrumelo as rootstock and grown in similar climatic conditions to those reported in this study.

Total polyphenolic contents were not affected by waxing, but they increased linearly with time $(\mathrm{Y}=31.3430+0.2417 \mathrm{x}$, $\left.\mathrm{R}^{2}=90.45 \%\right)$. The average values described in Table 2 are lower than that found by Gardner et al. (2000) in samples of orange juice (50.4 mg GAE/100 mL). Yellow flavonoids content in the waxed fruits differed from that of the control fruits $(\mathrm{p}<0.05)$, and the changing pattern during storage suggests an increase in the fruits in both treatments $\left(\mathrm{Y}=1.8322+0.0684 \mathrm{x}, \mathrm{R}^{2}<70 \%\right)$ (Table 2). Yellow flavonoids average was $3.6 \mathrm{mg} / 100 \mathrm{~g}$. This value is way lower than that found by Machado et al. (2009) for fieldripe 'Golden' pineapples grown in the same climatic conditions in Ceará state as those of the oranges studied in this experiment. Nonetheless, it is known that, besides climatic conditions, sugars derivatives of anthocianydins depend greatly on fruit variety.

\section{Conclusion}

'Delta Valencia' oranges grown in the local semiarid climatic conditions of Ceará state had green peel color after reaching physiological maturity and maintains the brightness of the peel, thus conserving the internal and external quality parameters of the fruits. 'Delta Valencia' oranges are sweet and of low acidity, with significant amount of juice and excellent quality. Fruit coating in association with cold storage maintains 'Delta Valencia' oranges high external quality for up to 28 days of storage.

\section{Acknowledgements}

The authors are grateful for the financial support provided by the Federal University of Ceará (UFC), Fundação Cearense de Apoio a Pesquisa e ao Desenvolvimento (FUNCAP), and to Banco do Nordeste do Brasil. We also acknowledge FrutaCor for providing the oranges used in this research.

\section{References}

ARPAIA, M. L.; KADER, A. A. Orange: Recommendations for maintaining postharvest quality. University of California, 2011. Disponível em: <http://postharvest.ucdavis.edu/producefacts/>. Acesso em: 15 dez. 2011.

ASSOCIATION OF OFFICIAL ANALYTICAL CHEMISTS. Official methods of analysis. 16th ed. Arlington: AOAC, 1995. $1141 \mathrm{p}$.

AULER, P. A. M.; FIORI-TUTIDA, A. C. G.; SCHOLZ, M. B. S. Qualidade industrial e maturação de frutos de laranjeira 'Valência' sobre seis porta-enxertos. Revista Brasileira de Fruticultura, v. 31, n. 4, p. 1158-1167, 2009. http://dx.doi.org/10.1590/S010029452009000400033

AZEVÊDO, C. L. L. Sistema de Produção de Citros para o Nordeste. Cruz das Almas: Embrapa Mandioca e Fruticultura, 2003. (Sistema de Produção, n. 16). Disponível em: <http://sistemasdeproducao. cnptia.embrapa.br/FontesHTML/Citros/CitrosNordeste/autores. htm >. Acesso em: 30 maio 2010.

BUCIC-KOJIC, A. et al. Study of solid-liquid extraction kinetics of total polyphenols from grape seeds. Journal of Food Engineering, v. 81, p. 236-242, 2007. http://dx.doi.org/10.1016/j.jfoodeng.2006.10.027

DEPARTAMENTO NACIONAL DE OBRAS CONTRA AS SECAS - DNOCS. Perímetro irrigado Jaguaribe-Apodi. Fortaleza: DNOCS, 2011. Disponível em: <http://www.dnocs.gov.br/ dnocs/ doc/canais/perimetros_irrigados/ce/jaguaribe_apodi.html >. Acesso em: 31 de ago. 2011.

FRANCIS, F. J. Analysis of anthocyanins. In: MARKAKIS, P. (Ed.). Anthocyanins as food colors. New York: Academic Press, 1982. p. 181-207. PMid:6764769 PMCid:272050.

GARDNER, P. T. et al. The relative contribuitions of vitamin C, carotenoids and phenolic to the antioxidants potencial of fruits juices. Food Chemistry, v. 68, p. 471-474, 2000. http://dx.doi. org/10.1016/S0308-8146(99)00225-3

HAGENMAIER, R. D. The flavor of mandarin hybrids with different coatings. Postharvest Biology and Technology, v. 24, p. 79-87, 2002. http://dx.doi.org/10.1016/S0925-5214(01)00121-1

HULME, A. C. The biochemistry of fruits and their products. London: Academic Press, 1970. v. 1, p. 620.

INSTITUTO ADOLFO LUTZ - IAL. Métodos físico-químicos para análise de alimentos. 4. ed. São Paulo: IAL, 2004. 1032 p.

LADANIYA, M. S. Citrus fruit: biology, technology and evaluation. Goa: Academic Press, 2008. p. 333. http://dx.doi.org/10.1016/B978012374130-1.50014-0

MACHADO, F. L. C.; OLIVEIRA, V. S.; COSTA, J. M. C. Postharvest quality of grapefruit (Citrus paradisi Macf.) produced from initial plantings in Ceará state, Brazil. Revista Ciência Agronomica, v. 42, n. 4, p. 883-888, 2011.

MACHADO, F. L. C. et al. W. Quality maintenance of ripe pineapple as affected by application of wax associated to 1-Methylcycloprene. Acta Horticultura, n. 822, p. 261-268, 2009.

MACHADO, F. L. C.; COSTA, J. M. C.; BATISTA, E. M. Application of carnauba-based wax maintains postharvest quality of 'Ortanique' tangor. Ciência e Tecnologia de Alimentos, v. 32, n. 2, p. 1-6, 2012.

MALGARIM, M. B.; CANTILLANO, R. F. F.; TREPTOW, R. O. Armazenamento refrigerado de laranjas cv. Navelina em diferentes concentrações de cera à base de carnaúba. Acta Scientiarum Agronomica, v. 29, n. 1, p. 99-105, 2007.

MILLER, G. L. Use of dinitrosalicylit acid reagent for determination of reducing sugars. Analytical Chemistry, v. 31, n. 3, p. 426-428, 1959. http://dx.doi.org/10.1021/ac60147a030

PEREIRA, G. S. et al. Teores de ácido ascórbico em laranja 'Valência' armazenada sob condição ambiente e refrigerada. In: SIMPÓSIO DE CIÊNCIA E TECNOLOGIA DE ALIMENTOS, 3., 2011, Recife. Anais... Recife, 2011.

RAPISARDA, P. et al. Effect of cold storage on vitamin C, phenolics and antioxidant activity of five orange genotypes [Citrus sinensis (L.) Osbeck]. Postharvest Biology and Technology, v. 49, p. 348354, 2008. http://dx.doi.org/10.1016/j.postharvbio.2008.02.002

STROHECKER, R.; HENNING, H. M. Analisis de vitaminas: métodos comprobados. Madrid: Paz Montalvo, 1967. 428 p.

TAZIMA, Z. H. et al. Comportamento de clones de laranja 'Valência' na região norte do Paraná. Revista Brasileira de Fruticultura, v. 30 , n. 4 , p. $970-974,2008$. http://dx.doi.org/10.1590/S010029452008000400022 
UNITED STATES DEPARTMENT OF AGRICULTURE - USDA. United States Standards for Grades of Florida Oranges and Tangelos. Washington: USDA, Agricultural Marketing Service, 1997.

VOLPE, C. A.; SCHÖFFEF, E. R.; BARBOSA, J. C. Influência da soma térmica e da chuva durante o desenvolvimento de laranjas 'Valência' e 'Natal' na relação entre sólidos solúveis e acidez e no índice tecnológico do suco. Revista Brasileira de Fruticultura, v. 24 , n. 2 , p. $436-441,2002$. http://dx.doi.org/10.1590/S010029452002000200031

YEMN, E. W.; WILLIS, A. J. The estimation off carbohydrate in plant extracts by antrone. Biochemical Journal, v. 57, n. 2, p. 504$514,1954$.

WU, T.; GUAN, Y.; YE, J. Determination of flavonoids and ascorbic acid in grapefruit peel and juice by capillary electrophoresis with electrochemical detection. Food Chemistry, v. 100, n. 4, p. 15731579, 2007. http://dx.doi.org/10.1016/j.foodchem.2005.12.042 